\title{
Extrarenal Retroperitoneal Angiomyolipoma: A Rare Case
}

\author{
Ekstrarenal Retroperitoneal Anjiyomiyolipom: Nadir Bir Olgu
}

\author{
Turgut Yapanoğlu', Ali Haydar Yılmaz', Tevfik Ziypak', Şenol Adanur', Elif Demirci², Habib Bilen ${ }^{3}$ \\ ${ }^{1}$ Atatürk University Faculty of Medicine, Department of Urology, Erzurum, Turkiye \\ ${ }^{2}$ Atatürk University Faculty of Medicine, Department of Pathology, Erzurum, Turkiye \\ ${ }^{3}$ Atatürk University Faculty of Medicine, Department of Internal Diseases, Erzurum, Turkiye
}

\begin{abstract}
Angiomyolipomas are benign tumors consisting of smooth muscles, vessels, and fat tissue. They are generally located on the kidneys; extrarenal angiomyolipoma is rare. Apart from the kidneys, angiomyolipomas are seldom located in the retroperitoneal area. Moreover, it is quite difficult to diagnose angiomyolipomas located in the retroperitoneal area. Due to the low amount of fat, negative density may not be identified by computed tomography (CT). The purpose of this report was to discuss the case of a retroperitoneal angiomyolipoma that clinically resembles a surrenal tumor and cannot be clearly discriminated from surrenal tissue on CT.
\end{abstract}

Keywords: Angiomyolipoma, density, kidney, retroperitoneum, tomography

Öz

Anjiyomiyolipomlar düz kas, damar ve yağ dokusundan oluşan benign tümörlerdir. Genellikle böbreğe yerleşirler, ekstrarenal anjiyomiyolipom nadir görülür. Anjiyomiyolipomun böbrek dışında retroperitoneal bölgeye yerleşimine oldukça az rastlanır. Retroperitoneal bölgeye yerleşen anjiyomiyolipomlara tanı koymak oldukça zordur. Yağ miktarının az olması nedeniyle bilgisayarlı tomografide (BT) negatif dansite saptanmayabilir. Bu olgu sunumumuzda klinik belirtileri sürrenal tümörü andıran ve BT'de sürrenal dokusuyla net ayrımı yapılamayan retroperitoneal anjiyomiyolipom olgusunu tartışmayı amaçladık.

Anahtar Kelimeler: Anjiyomiyolipom, dansite, böbrek, retroperiton, tomografi

\section{Introduction}

An angiomyolipoma (AML) consists of mature fat tissue, thick blood vessels, and soft muscle cells (1). AMLs are frequently located on the kidneys. Although most cases are sporadic, 20\% are accompanied by tuberous sclerosis (2). Retroperitoneal AML may cause abdominal pain and increased abdominal discomfort. The diagnosis of renal AML is established using computed tomography (CT), showing negative fat density [between -10 and -100 Hounsfield unit (HU)] with an accuracy rate of $86 \%$ $(3,4)$. In extrarenal AMLs, negative density may not be revealed due to the low amount of fat tissue, which complicates diagnosis (5). In our study, we discussed the rarely encountered case of a retroperitoneal AML.

\section{Case Presentation}

A 45-year-old male patient presented to our clinic with the complaint of pain on the right side of his body. A mass lesion ( $5 \times 6$ $\mathrm{cm})$, which could not be clearly discriminated from the surrenal tissue in the right retroperitoneal area, was identified using ultrasonography. Abdominal CT showed a mass lesion measuring $5 \times 6.5 \mathrm{~cm}$ with a density of $40 \mathrm{HU}$ on the right side that could not be clearly discriminated from the surrenal tissue (Figure 1). The patient, who occasionally suffered from blood pressure attacks, was pre-diagnosed with pheochromocytoma or adrenocortical carcinoma. He was prepared for surgery by the endocrine clinic. Informed consent was obtained from the patient.

The mass was reached employing the open retroperitoneal approach. The mass was found to be located between the

Correspondence: Ali Haydar YıImaz MD, Atatürk University Faculty of Medicine, Department of Urology, Erzurum, Turkiye Phone: +90 4423447975 E-mail: alicerrahcom@yahoo.com ORCID-ID: orcid.org/0000-0001-5797-0655

Received: 10.02.2016 Accepted: 25.03.2016

Cite this article as: Yapanoğlu T, Yılmaz AH, Ziypak T, Adanur Ş, Demirci E, Bilen H. Extrarenal Retroperitoneal Angiomyolipoma: A Rare Case. J Urol Surg 2017:4:134-136.

๑Copyright 2017 by the Association of Urological Surgery / Journal of Urological Surgery published by Galenos Publishing House. 
kidney and the surrenal tissue, independent of both organs. The whole mass was resected. Pathological examination of the lesion revealed vascular structures with thick walls containing no elastic lamina, mature adipose tissue focuses, and fascicles made of intense spindle cells around these structures. In the immunohistochemical examination, spindle cells were reactively identified through S100 SMA and Desmine HBM45. In the immunohistochemical study, S-100 reactivity was determined in the adipocyte areas, whereas CD34 and CD31 were positively identified in the vascular areas. The Ki-67 proliferative index was found to be low (5-10\%) in all three components of the tumoral formation. Based on all the data, the case was interpreted in favor of "retroperitoneal AML" (Figure 2).

\section{Discussion}

AML was defined in 1951 by Morgan et al. (6). It is characterized by various amounts of vessels, muscles, and fat tissues. Although it is substantially observed to be sporadic, it is accompanied by tuberous sclerosis in 20\% of cases. AML accompanied by tuberous sclerosis is frequent in the third or fourth decade of life and especially among women. These tumors are mostly observed to be asymptomatic, small, multifocal, and bilateral. Sporadic cases are observed as bigger, single, and unilateral masses (7) in patients aged between 40 and 70 years.

Tumors located in the retroperitoneal area are not common. The diagnosis before surgery is established via radiological screening. In the retroperitoneal area, lymph node metastasis

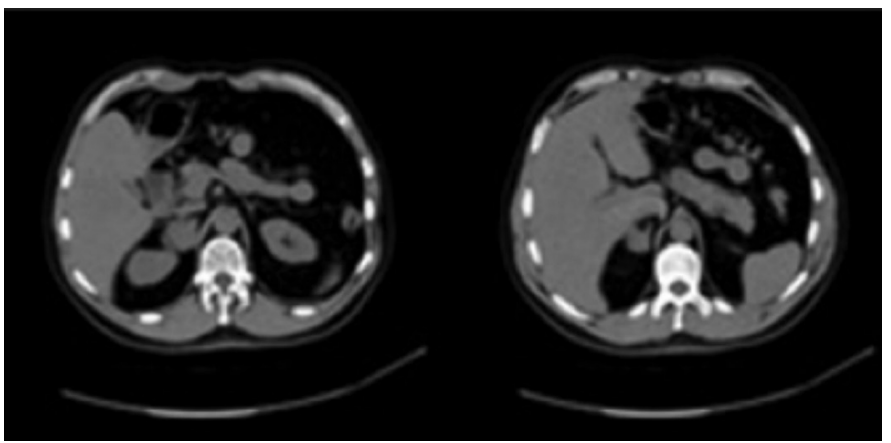

Figure 1. Mass with $5 \times 6 \mathrm{~cm}$ size is seen in right surrenal area in tomography

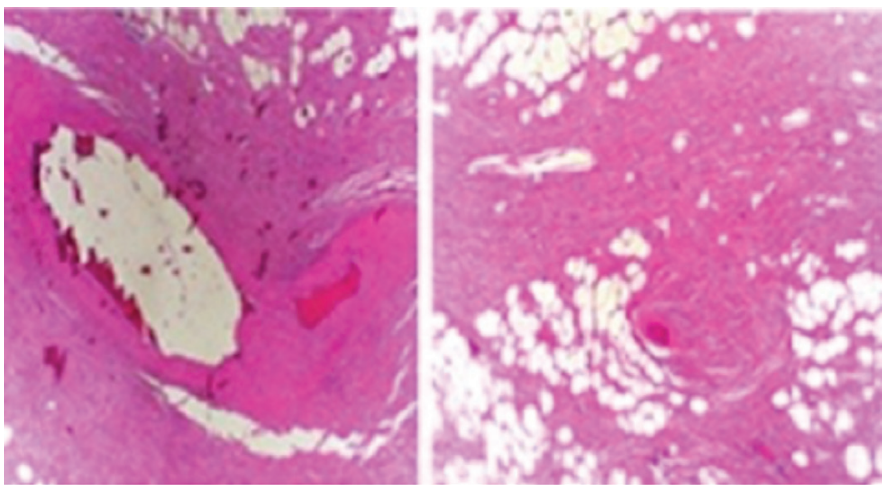

Figure 2. Microscopic image of lesion through hematoxylin and eosin may be observed after lymphoma, liposarcoma, leiomyosarcoma, schwannoma, paraganglioma, and testicular tumors (8). Retroperitoneal AML is a rare tumor. In the English literature, only 11 cases of retroperitoneal AML have been reported. Typically, these tumors grow towards the vascular pedicle and may cause abdominal pain and hemorrhagic shock (9). Although the radiological diagnosis of renal AML is straightforward, the diagnosis of extrarenal AML is difficult. Since fat density is low in these tumors, a negative density may not be identified, which complicates the diagnosis (10).

In our case, the density was measured as $40 \mathrm{HU}$ due to the low amount of fat. As it could not be clearly discriminated from the surrenal tissue on $\mathrm{CT}$, the mass lesion was thought to be primary surrenal tumor. However, in surgical exploration, the lesion was seen to be independent of the surrenal tissue. If AML could been diagnosed through radiology before surgery and the size of the tumor had been small, the patient could be managed via active surveillance. However, the patient has been operated on.

Consequently, the radiological diagnosis of renal AML is easy while the diagnosis of extrarenal retroperitoneal $A M L$ is more difficult. Since there is a lower fat density in these tumors, they may not be detected due to negative density.

\section{Ethics}

Informed Consent: Informed consent was obtained from the patient.

Peer-review: Externally peer-reviewed.

\section{Authorship Contributions}

Surgical and Medical Practices: T.Y., A.H.Y., Concept: T.Y., A.H.Y., Design: T.Y., A.H.Y., Data Collection or Processing: A.H.Y., E.D., Analysis or Interpretation: T.Y., T.Z., Ş.A., Literature Search: H.B., E.D., T.Z., S..A., Writing: T.Y., H.B., E.D.

Conflict of Interest: No conflict of interest was declared by the authors.

Financial Disclosure: The authors declared that this study received no financial support.

\section{References}

1. Strahan A, King J, McClintock S. Retroperitoneal angiomyolipoma: a case report and review of the literature. Case Rep Radiol 2013;457383.

2. Bissler JJ, Kingswood JC. Renal angiomyolipomata. Kidney Int 2004;66:924934.

3. Nelson CP, Sanda MG. Contemporary diagnosis and management of renal angiomyolipoma. J Urol 2002;168:1315-1325.

4. Tseng CA, Pan YS, Su YC, Wu DC, Jan CM, Wang WM. Extrarenal retroperitoneal angiomyolipoma: case report and review of the literature. Abdom Imaging 2004;29:721-723. 
5. Gupta C, Malani AK, Gupta V, Singh J, Ammar H. Metastatic retroperitoneal epithelioid angiomyolipoma. J Clin Pathol 2007;60:428-431.

6. Morgan GS, Straumfjord JV, Hall EJ. Angiomyolipoma of the kidney. J Urol 1951;65:525-527.

7. Tamboli $\mathrm{P}, \mathrm{Ro} \mathrm{JY}, \mathrm{Amin} \mathrm{MB}$, Ligato $\mathrm{S}$, Ayala AG. Benign tumors and tumorlike lesions of the adult kidney. Part II: Benign mesenchymal and mixed neoplasms, and tumor-like lesions. Adv Anat Pathol 2000;7:47-66.
8. Neville A, Herts BR. CT characteristics of primary retroperitoneal neoplasms. Crit Rev Comput Tomogr 2004;45:247-270.

9. Tsutsumi M, Yamauchi A, Tsukamoto S, Ishikawa S. A case of angiomyolipoma presenting as a huge retroperitoneal mass. Int J Urol 2001;8:470-471.

10. Hindman N, Ngo L, Genega EM, Melamed J, Wei J, Braza JM, Rofsky NM, Pedrosa I. Angiomyolipoma with minimal fat: can it be differentiated from clear cell renal cell carcinoma by using standard MR techniques? Radiology 2012;265:468-477. 